\title{
遺残結石症例の検討
}

\author{
久留米大学第 2 外科 \\ 友田信之中山和道
}

\section{STUDIES ON RESIDUAL STONES}

\section{Nobuyuki TOMODA and Toshimichi NAKAYAMA}

The Second Department of Surgery, Kurume University School of Medicine, Kurume

索引用㽞 : 遗残結石, 術中胆道精查, 胆道鏡下結石摘出術

\section{I. はじめに}

近年，わが国に拉ける胆石症は增加の傾向にある。そ の手術成績は術前検查の進歩, 術中胆道精查法の普及, 術後管理の向上などにより著しく向上した。しかし，遠 隔成績も考慮に入れると，術後も不快なる症状に悩まさ れる例も少なからずみられ，再手術を余儀なくされる症 例もある14.

これら術後の不満足例のうち, 最も大きな原因となる のが遺残結石例である. 本稿では当科に和ける遺残結石 例を検討し，その予防と対策につき述べる.

\section{II. 遗残結石应例の概要}

\section{a） 遺残結石の頻度}

1965年 1月より1980年12月までの16年間に当科で経験 した胆石症手術例は, 初回手術当科例 1,048 例, 他施設 例73例の計1,121例である．再手術時に 発見された結石 が遺残か 再発かの 判定は容易ではないが党3)，当科では 次のごとき基準をもって判定している.すなおち，(1) 初回手術時の結石がコレステロール系石で，ある期間を おいて再手術を行った時の結石がビリルビン系石のよう に, 初回手術時と再手術時の結石の種類が明らかに異な るもの, (2) 術前, 術中, 術後の直接胆道造影を中心之 した胆道検查データーが明確なもので, 遺残結石を確実 に否定でき，かつ術後 3 年以上無症状であったもの，(3)

絹系結石などを再発結石としている。一方，(4) 再手 術時の結石がコレステロール系石であったり，(5) 前回 の手術直後に Tチューブ造影などで結石を証明した例，

(6) 著者らの分類で I , II 型の肝内結石例は一応遺残結 石の範畴に入れている.この基準を当てはめると, 初回

*第18回日消外会総会シンポI

遺残胆石の対策
手術当科例 1,048 例における遺残結石の頻度は32例（3.1 \%)である．ところで遺残結石には，術中見逃し例と， 肝内結石例などで遗残は承知であるが，手技的あるいは 時間的にやむをえないるのとに大別できる. 遺残結石 32 例の5ち訳は, 総胆管結石17例中, 16例が術中見逃し例 で, 1 例のみは high risk のためやむなく残したもので ある. 肝内結石15例中，5例は結石の見逃し 例である が，他の10例は衍中完全摘出ができずに遺残となった あのである.な抽, 再発結石と考光られたるのは 4 例 （0.4\%）にすぎなかった。一方, 初回手術他施設例で 再手術を当科で行った症例が73例あり，このうち68例 （93\%）か遺残結石例であった（表 1 ).

\section{表 1 遗残結石の頻度}

\begin{tabular}{|c|c|c|c|c|c|c|}
\hline \multirow{3}{*}{$\begin{array}{l}\text { 診断名 } \\
\text { 胆要秸石 }\end{array}$} & \multicolumn{3}{|c|}{ 初回手術·当科例 } & \multicolumn{3}{|c|}{ 初回手術·他施砓例 } \\
\hline & \multirow{2}{*}{$\frac{\text { 例数 }}{7663}$} & \multicolumn{2}{|c|}{ 遭残秸石例 } & \multirow{2}{*}{$\begin{array}{c}\text { 例数 } \\
3\end{array}$} & \multicolumn{2}{|c|}{ 㟟残䅅石例 } \\
\hline & & 0 & $0 \%$ & & 2 & B6.7x \\
\hline 秷筑管䊰石 & 242 & $\begin{array}{l}17 \\
\text { (16) }\end{array}$ & $\begin{array}{l}7.0 \% \\
(6.6 \%)\end{array}$ & 38 & 34 & 39.5\% \\
\hline 肝内䊀石 & 43 & $\begin{array}{l}15 \\
(5)\end{array}$ & $\begin{array}{l}34.8 \% \\
(11.8 \%)\end{array}$ & 32 & 32 & $100,0^{\circ}$ \\
\hline 棓 & 1048 & 32 & \begin{tabular}{|l|l}
$3.1 \%$ \\
$(2.00)$
\end{tabular} & 73 & 68 & $93.2 x$ \\
\hline
\end{tabular}

b）遺残結石の原因

初回手術当科例で術中見逃し例21例に和ける遗残の原 因を, 術中胆道精査のなかで routine で重要な検査法で ある術中胆道造影所見について, retrospective に検討す ると表 2 の如くである． 総胆管結石16例中 8 例 (50\%), 肝内結石 5 例中 1 例 $(20 \%)$ が，術中胆管造影あるいは 術中再検胆管造影を急ったもので，基本的なミスが原因 であった．次に術中造影を行ったが，造影法そのるのに 問題があったものが 7 例あり，4 例は肝内胆管の造影不 
表 2 遗残結石の原因（初回手術当科例）

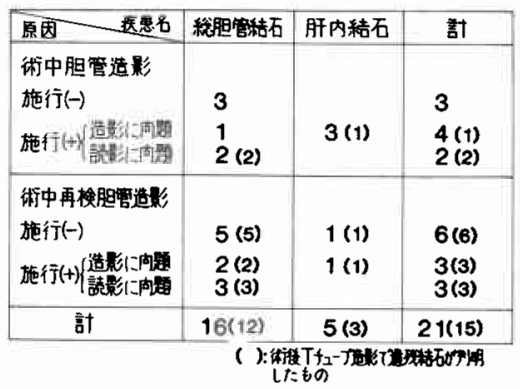

表 3 総胆管結石再手術例の術式

\begin{tabular}{|c|c|c|c|}
\hline & \multicolumn{2}{|c|}{ 初回手術 } & \multirow{2}{*}{ it } \\
\hline & 当科 & 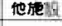 & \\
\hline 1 盟宿切用ドレナージ & 5 & 11 & 16 tases \\
\hline 2 (1)十乳頭形成術 & 3 & 10 & $13(283 *)$ \\
\hline 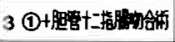 & 3 & 8 & 11 cassow \\
\hline 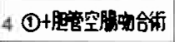 & & 3 & 3 \\
\hline 5 (2)+胆管形成術 & 1 & 1 & 2 \\
\hline 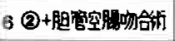 & & 1 & 1 \\
\hline 計 & 12 & 34 & 46 \\
\hline
\end{tabular}

充分，3例は撮影条件の不充分が原因と考之られた。ま た，読影汇問題があったと考えられる症例は 5 例で，そ のうち 3 例は胆管像が十二指腸や椎骨と重なったために 結石を見逃した例で，2 例は気泡と読みちがえたるので ある。

c）遺残総胆管結石に対する治療

衰了遣残総胆管結石に扮ける再手術術式である. 初回手術当科例に打ける遺残総胆管結石17例中12例 (71 \%) に再手術を行った，他の 5 例は昭和52年以後の症例 であるが，Tチニーブによる瘦孔残存中に発見されたる ので，胆道鏡下に非観血的結石摘出を行った。初回手術 他施設例 34 例を含めた46例中30例 $(65.2 \%)$ に付加手術 が行われたが，その内訳は乳頭形成術15例，胆管十二指 晹吻合術11例, 胆管空腸吻合術 4 例である. 乳頭形成術 15例中10例 (66.7\%) は合併した乳頭狭窄に対し施行さ れたるのである。胆管十二指腸吻合術は昭和 49 年以前に 行ったもので, 逆行性胆管炎から肝膿瘍を合併した 2 症 例を経験したため，現在では全く行っていない，手術死 亡例は46例中 1 例 $(2.2 \%)$ で, 急性閉塞性化膿性胆管 炎症例であった. なお，結石の種類別ではビリルビン系 石32例 $(70 \%)$ ，コレステロール系石14例 $(30 \%)$ であ った. 次に非観血的結石摘出例を供覧する.
因 1 術後胆道造影, 総胆管末端部に 2 個の遗残結 石（矢印）を認める。

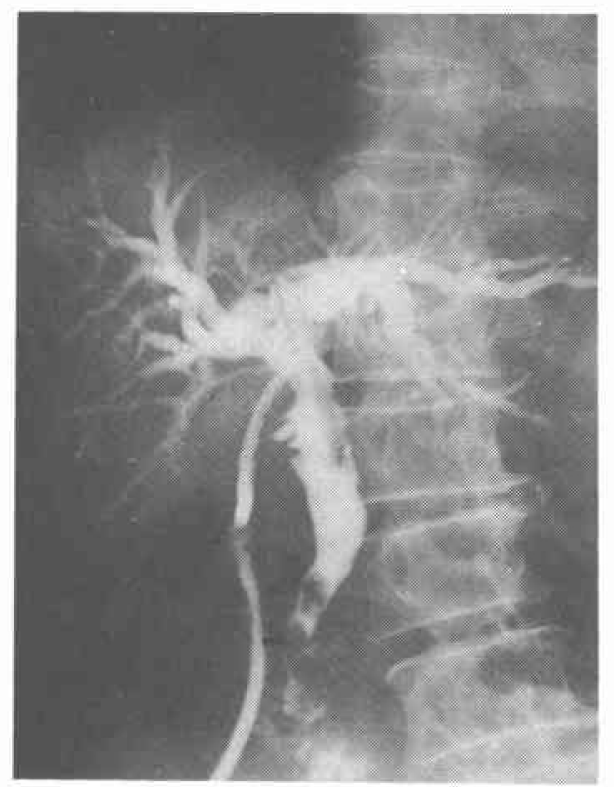

症例 1.72 歳, 女性.

胆襄, 総胆管結石症にて胆摘, 総胆管切開截石術兼 $\mathbf{T}$ チューブドレナージを施行した。術後胆道造影では総胆 管末端部に 2 個の 遣残結石を認める(図 1). 本例は術 中胆道鏡，さらに閉腹前の再検胆道造影をも意ったもの

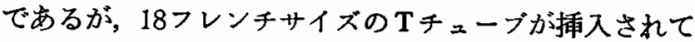
おり，瘦孔の完成をまって胆道鏡下に結石を摘出した。 图 2 左は瘦孔を通して胆道鏡を挿入中のところで，右は 摘出後の胆管造影であるが結石は認めない.

d) 付加手術について

次に遺残結石の予防対策としての付加手術の問題にふ れる. 表 4 は胆石症手術に括ける付加手術の频度を示し たものである.全体としては1,121例中172例 (15.3\%) に行われ，内訳は胆䫔結石766例中15例 (2\%), 総胆管 結石 280 例中 91 例 $(32.5 \%)$,肝内結石75例中66例 (88\%) である. 表 5 はその適応を示したものである. 肝内結石

表 4 胆石症に於ける付加手術

\begin{tabular}{|c|c|c|c|c|c|}
\hline & 症例数 & 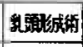 & 然社 & 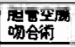 & 計 \\
\hline 盟禹結石 & $768(68)$ & 13 & 2 & 0 & $15(20)$ \\
\hline 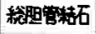 & $280(280)$ & 59 & 23 & 9 & $91(32.5)$ \\
\hline 肝内結石 & 75 (a.) & 29 & 7 & 30 & 66roac) \\
\hline 部 & 1121 & 101 & 32 & $39^{*}$ & 172(16:a) \\
\hline
\end{tabular}


図 2 術後胆道鏡下結石除去例，左 : 胆道鏡下に截石中, 右 : 摘出後の胆管造影

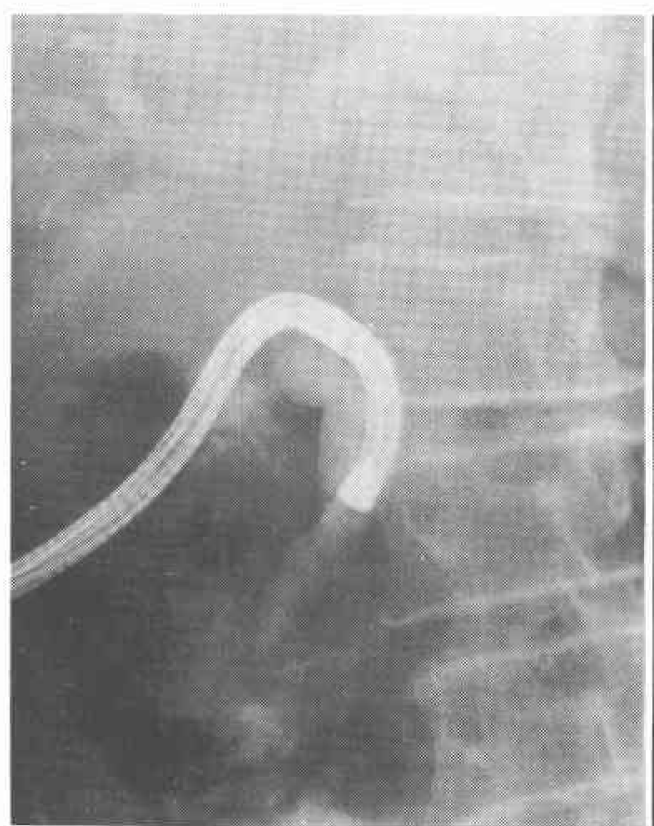

表 5 付加手術の適応

\begin{tabular}{|c|c|c|c|c|}
\hline & 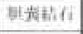 & 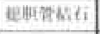 & Helasidi & Al \\
\hline Alutither & 11 & 35 & & 46 \\
\hline $\begin{array}{l}\text { Whorite } \\
\text { Hol }\end{array}$ & & it & & 17 \\
\hline 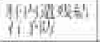 & & & 66 & 86 \\
\hline 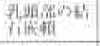 & & 13 & & 13 \\
\hline 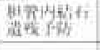 & & 15 & & 15 \\
\hline Huter & 4 & 6 & & 10 \\
\hline thote & & 5 & & 5 \\
\hline if & 15 & 91 & 66 & 172 \\
\hline
\end{tabular}

例では当然としても, 総胆管結石例でも91例中15例 (17 \%) が，胆管内結石遗残予防の 理由で付加手術が行わ れている.ところで, 遺残総胆管結石の大多数は術後 Tチューブよりの造影で発見され, 結石の数も $1 \sim 2$ 個 の少数である場合が多い,さらに, 最近では胆道鏡下に 行ら機诚的摘出術の進歩により, 術後に非観血的に処理 することが容易となった．総胆管結石例で遺残の可能性 を100\%否定できない場合でも，最近ではそれだけの理 由で安易に付加手術を行わずに，20フレンチサイズ以上 の Tチューブを総胆管内に挿入し皮虐と直角に体外に誘 導し，術後の非観血的処圆にそなえている.な㨁，遗残 総䏣管結石例で再手術を行った46例の中には, 昭和51年

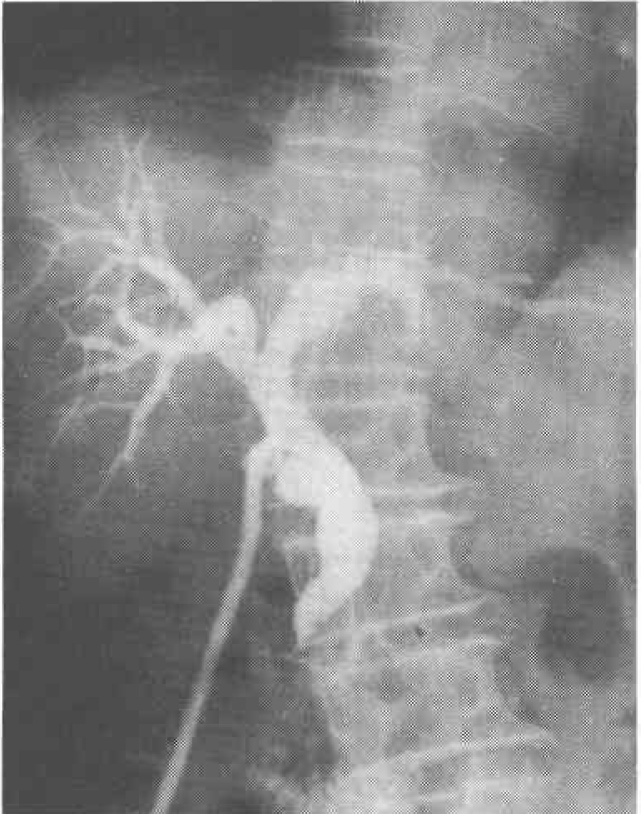

以前の症例であるか， Tチューブによる瘦孔残存中に発 見されたものが8例含まれている。これらは，挿入され たTチューブが細かったり，または，瘻孔と胆管の交叉 する角度から胆道鏡を目的とする部位に挿入することが 困難なため，再手術となったものである．チューブの口 径や扦入方向に留意することが大切であると痛感され た。

e）肝内結石症に対する治療上の問題点について 肝内結石症75例中, 再手術例が37例 (49.3\%) を占め ており，本症に対する治療法の確立が胆石症手術成績向 上策のうえで重要な課題となる. 本症の病型分類は現在 に敃いても画一的なものはないが，著者らは手術術式の 選択に合目的である，胆管狭窄部に重点を颃いた分類 を行っている2)．Ｉ型は肝内胆管狭窄型で，I型をさら V I R (右肝内胆管狭窄型)，I（左肝内胆管狭窄型), I B (両僋肝内胆管狭窄型) に分けた。II 型は上部胆管 狭窄型で主に肝門部付近に狭窄がみられるるの. III型は 下部胆管狭窄型で, 主に乳頭部に狭窄があり胆管の扗張 が著明なるの. IV 型は胆管非狭窄型である.

本症に対する外科的治療の基本方針は，可及的結石摘 出と胆汁うっ帯の解除である. 病型別にみた詳しい術式 の選択については紙面の都合上他誌にゆずるが2)，I 型 一肝切除術, II 型一胆道再建術, III型一付加手術, IV型 
表 6 病型別最終手術術式 (1980. 12)

\begin{tabular}{|c|c|c|c|c|c|c|c|c|}
\hline \multicolumn{2}{|r|}{ 術式病型 } & $\mathrm{L}_{\mathrm{R}}$ & $\mathrm{I}_{\mathrm{L}}$ & $\mathrm{I}_{\mathrm{B}}$ & II & III & IV & 計 \\
\hline 1 & 胆管切開ドレナージ & & & & & 2 & 1 & 3 \\
\hline 2 & (1)+乳頭形成術 & 1 & & 1 & & 12 & 4 & 18 \\
\hline 3 & $\begin{array}{l}\text { (1)十胆管十二指腸吻合術 } \\
\text { (Roux-Y) }\end{array}$ & & & & & 7 & & 7 \\
\hline 4 & $\begin{array}{l}\text { (1)十胆管空腸吻合術 } \\
\text { (Roux-Y) }\end{array}$ & 2 & 3 & & & 5 & & 10 \\
\hline 5 & $\begin{array}{l}\text { (1) +肝内外二重胆管空腸吻合術 } \\
\text { (Roux-Y) }\end{array}$ & & 1 & & & & & 1 \\
\hline 6 & $\begin{array}{l}\text { (1) + 肝門部胭管空腸吻合術 } \\
\text { (Roux-Y) }\end{array}$ & 2 & 1 & 1 & 8 & 1 & & 13 \\
\hline 7 & (1)十肝切除術 & 1 & 4 & & & & & 5 \\
\hline 8 & (7)+乳頭形成術 & & 10 & & & & & 10 \\
\hline 9 & $\begin{array}{l}\text { (7)+胆管空腸吻合術 } \\
\text { (Roux-Y) }\end{array}$ & & 1 & 1 & & & & 2 \\
\hline 10 & $\begin{array}{l}\text { (7)+肝門部胆管空腸吻合術 } \\
\text { (Roux-Y) }\end{array}$ & & 1 & 2 & 1 & & & 4 \\
\hline 11 & 肝内胆管切開截石術 & & 1 & & & & & 1 \\
\hline 12 & (2)十胆管形成術 & & & & 1 & & & 1 \\
\hline & 計 & 6 & 22 & 5 & 10 & 27 & 5 & 75 \\
\hline
\end{tabular}

表 7 結石遺残率

\begin{tabular}{|c|c|c|c|c|}
\hline \multicolumn{3}{|c|}{ 病型 遗残率 } & 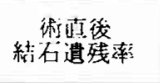 & $\begin{array}{c}\text { 退院時 } \\
\text { 結石遭残率 }\end{array}$ \\
\hline \multirow{3}{*}{ I } & $I_{L}$ & 22 & $6 / 22(27.3)$ & $4 / 22(18.2)$ \\
\hline & $I_{R}$ & 6 & $5 / 6(83.3)$ & $4 / 6(66.7)$ \\
\hline & $\mathbf{I}_{B}$ & 5 & $3 / 5(60.0)$ & $3 / 5(60.0)$ \\
\hline \multicolumn{2}{|c|}{ II } & 10 & $9 / 10(90.0)$ & $4 / 10(40.0)$ \\
\hline \multicolumn{2}{|c|}{ III } & 27 & $6 / 27(22.2)$ & $5 / 27(18.5)$ \\
\hline \multicolumn{2}{|c|}{ IV } & 5 & $1 / 5(20.0)$ & $0 / 5\left(\begin{array}{ll}0 & 0\end{array}\right)$ \\
\hline \multicolumn{2}{|c|}{ 計 } & 75 & $30 / 75(40.0)$ & $20 / 75(26.7)$ \\
\hline
\end{tabular}

一胆管ドレナージの如き原則的手術術式で手術に臨んで いる.表6は病型別にみた最終手術術式である。I 型で は33例中20例 (61\%) に肝切除術が行われたが，その 内訳は左肝外側区域切除術15例，左葉切除術 3 例，右 葉切除術 2 例である. II 型では肝門部胆管空腸吻合術 (Roux-Y) が 9 例に行われ，1 例には左肝外側区域切除 術が追加されたＩII型では27例中25例（93\%）に付加手 術を行ったＩV型では 5 例中 4 例に遗残結石の予防的意 味で乳頭括約筋形成術を行っている。

表 7 は結石遺残率を示したものである．術後胆管造影 や術後胆道鏡にて, 術直後に遺残結石が認められたもの
は75例中30例 (40\%)である.とくに I R, II，I B 型で は遺残率が高い，術中においては，胆道内視鏡的摘出 を含む結石题，結石鈿子，洗浄なとにより可及的に結石 を摘出する.しかし，摘出不能または時間的余裕のない 場合には，遺残結石を消化管内に流出させる付加手術を 行い, この際術後の遺残結石除去処置が行いやすいよう に経肝性（または経腸的）に胆道ドレナージチューブを 插入する. 術後の結石除去法としては, 溶解斉による化 学的方法と物理的方法があるが, 現在最す有效な手段は 胆道鏡下に行ら機械的結石摘出術である. 瘦孔の完成を まって, 術後約 3 週間目にドレーン抜去後の瘦孔を介し て結石摘出に努めている. 可能なかぎり非観血的結石除 去を行った後の退院時結石遺残率は26.7\%で，かなりの 効果がみられる.しかし，IR，I B 型ではな扣完全除 去困難な例も少なくない。

\section{III. 考 察}

胆石症再手術の大多数は遺残または再発による胆道結 石例である.再手術時に発見された結石か゚遺残か再発か の判定は容易ではないが, 前述の如き基準によれば, 初 回手術当科例 1,048 例中, 遺残32例 (3.1\%), 再発 4 例 (0.4\%) である. 一方, 初回手術他施設例73例中, 遗 残68例 $(93.2 \%)$, 再発 5 例 $(6.8 \%)$ であり, 諸家の報 告と一致して大多数は遺残結石例である. 
これら遺残結石の予防対策としては，まず術前の排泄 性胆道造影, 直接胆道造影による適確なる病変部の把握 が重要である．また，肝内結石のスクリーニングには超 音波検査が第一選択の検査法となる. 次に術中胆道精査 法があるが，この中でも routine な術中胆道造影の施 行, 適応に応じての胆道内視鏡の活用が重要である. 術 中胆道造影所見について遺残の 原因を retrospective に 検討すると, 胆道造影に際しては，(1) 空気の混入をさ ける. (2) 肝内胆管に 造影剤が 充分入るように，20度 head down, 45度第 1 斜位で造影剂を注入する. (3) 十 二指晹, 椎骨とのかさなりに対しては撮影時に $5 \sim 10$ 度 第 2 斜位にする. (4) 腹壁の厚さを術前に測定してお き，術中に正確なる撮影条件を決定する，などが重要と 考觉らるるまた，術中見逃し21例中15例は，術後 Tチ ニーブ造影で遺残結石が判明したもので，このうち6 例 は再検胆管造影を意ったものである．Tチューブ挿入例 では結石完全除去確認としての, 閉腹前における再検胆 管造影の重要性を強調したい.

遺残結石を予防する上での手術手技としては，胆㷮内 に小結石が多数認められる症例では早期に胆蓄管を結禁 し, 結石の胆管内への落下を防止することが必要であ る. 一方, 胆管内結石例では, 小結石や胆砂が多数認め られ，術中に全結石を摘出したと思われてもなお遺残の 可能性を100\%否定できない場合は, 予防的意味で乳頭 形成術を行らこともあるが4, 最近では術後の非観血的 な結石除去法が進歩しており，とくに初回手術例では乳 頭括約筋の機能はなるべく温存すべきであろう。なお， この場合には術後の処值が行いやすいように，Tチュー ブはある程度の太さのもの（20フレンチサイズ以上）を 皮膚に直角に挿入して括くと便利である。

遺残結石に対する再手術術式として特別な方法はない が，病態に応じた適切なる術式の選択が必要となる。

最近では， $\mathrm{T}$ tube 瘦孔などの胆管への直接到達経路 がない遗残胆道結石に対する非手術的方法として, 内視 鏡的乳頭括約筋切開術が行われている. 本法の適応につ いては，相馬 ${ }^{5)} は$ 少なくとも再手術例や high risk の患
者の遺残結石に対しては first choice の方法であると述 べている、しかし，出血，膵炎，胆管炎，穿孔なとの合 併症が，わが国の集計で7.3\% ，外国では Safrany ${ }^{7)} の$ 1978年の 集計で $7.0 \%$ みらる. 死亡率はわが国で 0.4 \%，外国では1.4\%である．本法の施行に際しては，慎 重に適応をえらび，合併症に対する万全の対策を講じて 行われるべきである ${ }^{5) 6}$.

肝内結石例では複雑多彩な病態のため, 術中に完全摘 出が困難な例が多い. 結石摘出不能な時は, 術後の遺残 結石除去処置が行いやすいように胆道ドレナージチュー ブを挿入し，沺後の非観血的摘出につとめる．現段階で 最も有効な方法は胆道鏡下に行う機㖑的結石摘出術であ り，従来の洗浄法とともに積極的に繰り返し行われるべ きである8).

\section{IV. おわりに}

胆石症手術における遺残結石の予防と対策につき述べ た.とくに肝内結石症では, 病型に応じた術式の選択と ともに, 術後の非観血的治療法の重要性を強調した.

\section{文献}

1）佐藤寿雄，畑中恒人，小林信之ほか：胆石症の 再手術例について。外科治療, $29 ： 123-130$, 1973.

2) 中山和道, 友田信之：肝内結石症の外科的治 療。日本医事新報，2964：7-12，1980。

3) 高田忠敬, 安田秀喜 : 遺残結石と非観血的治療 法. 胆石症初診から治療まで。東京, 医学書 院, 1980, p 130-140.

4) 羽生富士夫, 高田忠敬, 中村光司汪か: 遺残結 石. 臨床外科, $31: 1549-1559,1976$.

5) 相馬智, 小野美贵子, 藤田力也 : 内視鏡的乳頭 括約筋切開術のトラブルと対策. 臨床外科, 35: 1401-1407, 1980 .

6) 中島正継：内視鏡的乳頭括䄪筋切開術の適応と 意義。胆石症初診から治療玉で. 東京, 医学書 院, 1980, p 200-209.

7) Safrany, L.: Endoscopic treatment of biliary-tract disease. An international study. Lancet, Noo., 4: 983, 1978.

8) 山川達郎 : 肝内結石症に対する付加療法. 消化 器外科, $4: 547-555,1981$. 